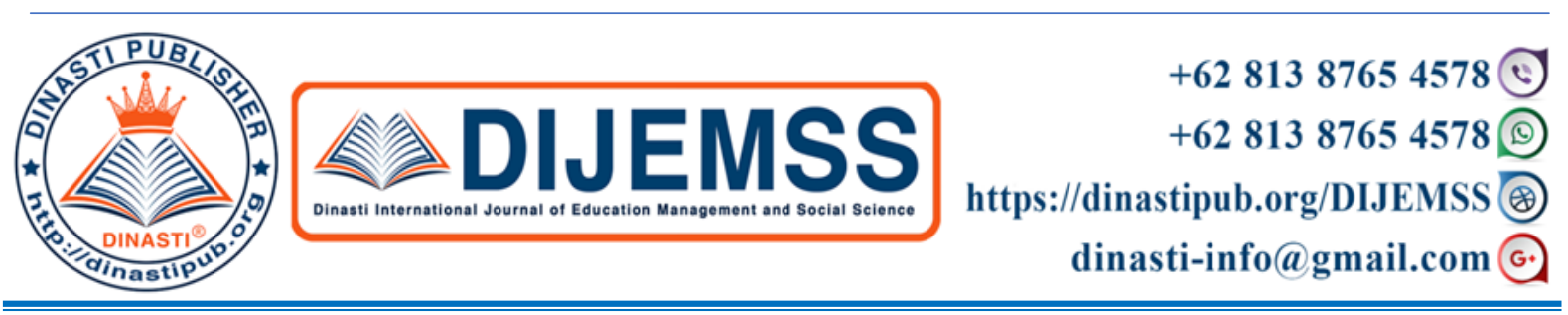

\title{
ANALYSIS OF PRODUCTION PERFORMANCE BASED ON GREEN SUPPLY CHAIN MANAGEMENT CRITERIA
}

\author{
Yudiansyah $^{1)}$, Tukhas Shilul Imaroh ${ }^{2)}$ \\ ${ }^{1,2}$ Universitas Mercu Buana, Jakarta, Indonesia
}

\begin{tabular}{|c|c|}
\hline $\begin{array}{c}\text { ARTICLE INFORMATION } \\
\text { Received: } 2^{\text {nd }} \text { July } 2020 \\
\text { Revised: } 25^{\text {th }} \text { July } 2020 \\
\text { Issued: } 22^{\text {th }} \text { August } 2020 \\
\text { Corresponding author: } \\
\text { First Author } \\
\text { E-mail: } \\
\text { yudiansyah_sukmana@yahoo.com } \\
\text { tukhas.shilul@mercubuana.ac.id }\end{array}$ & $\begin{array}{l}\text { Abstract: PT. XYZ is one of the companies engaged in the } \\
\text { salt processing industry in Indonesia. The development of } \\
\text { this industry, in addition to having a positive impact on the } \\
\text { economy also has the potential for negative impacts on the } \\
\text { environment if not managed properly. This condition is } \\
\text { inseparable from the production process which produces } \\
\text { many defects and rejects. One way to reduce these negative } \\
\text { impacts is by measuring performance that is integrated with } \\
\text { the environment (Green Supply Chain Management). The } \\
\text { researcher uses the green SCOR model which refers to the } \\
\text { SCOR (Supply Chain Operation Reference) model from the } \\
\text { Supply Chain Council to identify green supply chain } \\
\text { management performance indicators. Then use AHP } \\
\text { (Analytical Hierarchy Process) to determine the level of } \\
\text { importance of green supply chain management performance } \\
\text { indicators. There are six categories of processes used in } \\
\text { measuring the performance of green supply chain } \\
\text { management, namely plan, source, make, deliver, return and } \\
\text { waste management, but research is focused on the make } \\
\text { process that focuses on the salt production process. The } \\
\text { results of measurements indicate that the value of the } \\
\text { performance of green supply chain management of PT. XYZ } \\
\text { in } 2017 \text { amounted to } 75.4 \text { and } 2018 \text { amounted to } 72.3 \text { is still } \\
\text { below } 80 \text { even though it is nearing the target but is still being } \\
\text { controlled and efforts are made to improve. But when in } \\
2019 \text { it decreased to } 46.6 \text { which shows far below the target } \\
\text { and needs to be done immediately. As for the } 17 \\
\text { performance indicators measured, there are } 9 \text { performance } \\
\text { indicators that need to be improved, namely reusable } \\
\text { material, the number of machine troubles, the number of } \\
\text { process rejects, recycleable rejects, the amount of waste, the } \\
\text { amount of product defects, recycleable defects, production } \\
\text { costs and waste handling costs. } \\
\text { Keywords: Salt processing industry, performance } \\
\text { measurement, green supply chain management, green SCOR, } \\
\text { AHP }\end{array}$ \\
\hline
\end{tabular}

\section{INTRODUCTION}

Currently the industrial sector continues to grow, so that all aspects contained in an industry will determine the success and progress of the industry. One aspect that determines success is high productivity. High productivity can be achieved with an efficient and effective 
process where raw material is converted into finished goods with little reject or defect during the production process. So that it can be a competitive advantage in terms of cost leadership in order to win competition in the market for satisfaction and retain customers and get new customers.

In its development, in general, customers of PT. XYZ began to demand aspects of the speed of response, innovation and flexibility in salt delivery. In addition, PT. XYZ must be able to compete with its competitors by increasing production performance through the efficiency of several stages of production in order to achieve more efficient production costs. When viewed from the point of view of green supply chain management, it can be seen that in the production process there are still many process reject and product defect, and this results in a decline in production performance.The following is product defect data during the production process from January 2017 to July 2019.

Table 1. Number of Product Defect of PT. XYZ (tons)

\begin{tabular}{|r|r|r|r|r|r|r|r|r|r|r|r|r|r|r|}
\hline Year & Jan & Feb & Mar & Apr & May & Jun & Jul & Aug & Sep & Oct & Nov & Dec & Total & AVG \\
\hline 2017 & 11 & 3 & 8 & 8 & 136 & 14 & 122 & 6 & 46 & 76 & 8 & 91 & 529 & 44 \\
\hline 2018 & 208 & 44 & 10 & 23 & 2 & 67 & 44 & 54 & 37 & 97 & 152 & 18 & 756 & 63 \\
\hline 2019 & 130 & 72 & 53 & 21 & 14 & 13 & 63 & & & & & & 366 & 52 \\
\hline
\end{tabular}

(Source: PT. XYZ Periode from January 2017- July 2019)

In addition to product defects, rejects occur during the production process. The following reject data from January 2017 to July 2019.

Table 2. Number of Process Reject PT. XYZ (tons)

\begin{tabular}{|r|r|r|r|r|r|r|r|r|r|r|r|r|r|r|}
\hline Year & Jan & Feb & Mar & Apr & May & Jun & Jul & Aug & Sep & Oct & Nov & Dec & Total & AVG \\
\hline 2017 & 164 & 132 & 131 & 78 & 108 & 94 & 100 & 97 & 52 & 80 & 92 & 126 & 1.254 & 105 \\
\hline 2018 & 133 & 130 & 105 & 64 & 136 & 71 & 85 & 95 & 112 & 80 & 63 & 75 & 1.149 & 96 \\
\hline 2019 & 57 & 75 & 25 & 162 & 79 & 88 & 103 & & & & & & 588 & 84 \\
\hline
\end{tabular}

(Source: PT. XYZ Periode from January 2017- July 2019)

The high number of product defect and process reject results in not achieving the production target and ineffective use of raw materials. Therefore it is necessary to do a research on production performance based on green supply chain management criteria.

In the previous research in its journal, it gave recommendations for improvements to the company in improving the performance of the tea business units that had not reached the target, resulting in 31 valid KPIs consisting of $18 \mathrm{KPI}$ reaching the target and $2 \mathrm{KPI}$ approaching the target and $11 \mathrm{KPI}$ far below the target [1]. Other research states that the use of a small amount of raw materials can reduce waste in GSCM implementation and minimize the cost of handling waste and can benefit from the waste itself [2]. Furthermore, other previous research in his journal with a focus on the implementation of GSCM practices in Pekalongan batik SMEs resulted that the strategy to improve GSCM practices in Pekalongan batik SMEs was more focused on improving the performance indicators of the use of environmentally friendly raw materials [3].

Based on previous studies, it is necessary to measure the performance of green supply chain management in a company. The aim is to determine the company's performance conditions in terms of the environment and to reduce negative impacts on the environment. By measuring production performance based on green supply chain management criteria, we will find indicators thar are considered weak which can be given recommendations to improve the performace based on GSCM criteria. GSCM performance measurement can be done with the Green Supply Chain Operation Reference (GreenSCOR) model. 


\section{LITERATURE REVIEW}

\section{Supply Chain Management}

Supply chain management is an issue that is currently being discussed. Supply chain management is related to a complete cycle of material incoming from suppliers, operational activities in the company, and distribution to consumers [4].

Supply chain management is efforts to manage the stages contained in the supply chain to produce maximum profit of the company. Supply chain management as an integrative philosophical conception to regulate the flow of a channel from the earliest raw material suppliers to the end users [5]. Supply chain management as a unit that is interconnected between components with one another that has random variations that can affect the performance of a chain.

\section{Green Supply Chain Management}

Green supply chain management as a process of using environmentally friendly inputs and turning those inputs into outputs that can be reused at the end of its life cycle so as to create a sustainable supply chain [6]. There are several operational functions and activities in GSCM, namely Green Procurement, Green Manufacturing, Green Distribution, and Logistics Reverse (Reverse Logistic) as shown in Figure 2.1 [7].

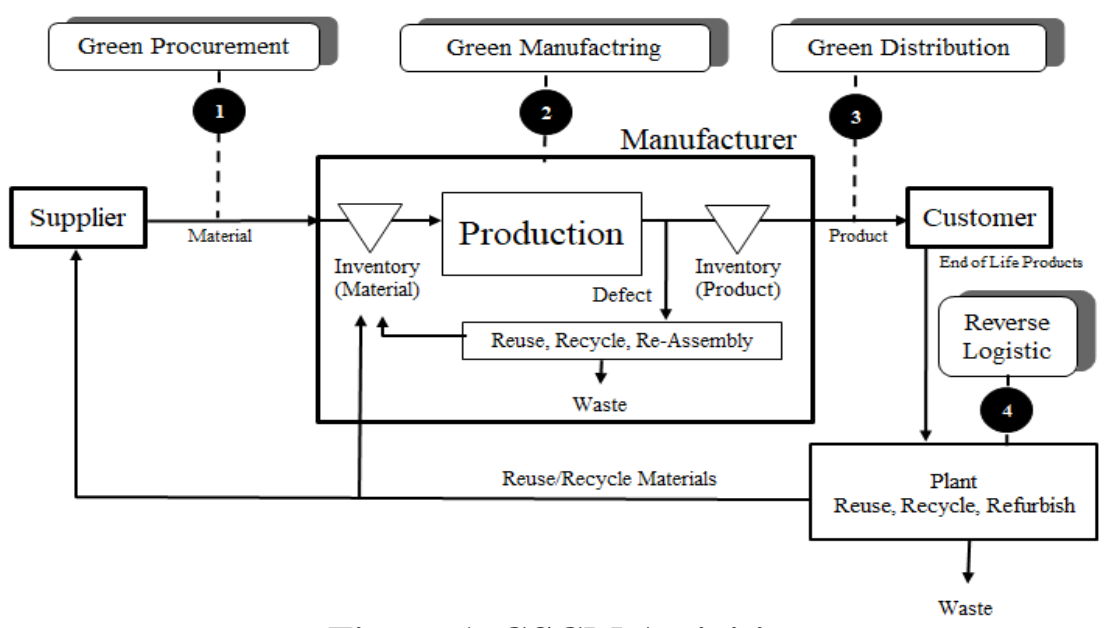

Figure 1. GSCM Activities

Green supply chain management (GSCM) or sustainable supply chain management (SSCM) has been an area that has continued to be in demand for research for several decades and is a major challenge for companies in developing supply chains. Changes in the new industrial era that demanded the role of industry in protecting the environment by reducing waste and pollution, led to the emergence of green supply chain management in the implementation of supply chain strategies [8].

\section{Green Supply Chain Operation Reference (GreenSCOR)}

The GreenSCOR model is the result of the development of the existing SCOR model. This GreenSCOR model adds several considerations related to the environment within it. That way this model is used as a tool to manage the environmental impact of a supply chain. The aim is to create an analysis that will provide an overview of the relationship of supply chain functions with environmental aspects in order to create improved management performance between the two [9].

The SCOR model has 5 key processes namely plan, source, make, deliver and return [10]. Whereas in the greenSCOR model, these processes have different meanings. The difference lies in the addition of environmental elements, so the process category of the greenSCOR model is as follows [10][11]: 
Table 3. Environmental Impacts of the GreenSCOR Process

\begin{tabular}{|c|c|}
\hline $\begin{array}{l}\text { GreenSCOR } \\
\text { Category }\end{array}$ & Impact \\
\hline Plan & $\begin{array}{l}\text { - Plans to minimize the energy consumption and use of } \\
\text { hazardous materials. } \\
\text { - Plans for proper handling and storage of hazardous materials. } \\
\text { - Plans for regular and hazardous waste disposal. } \\
\text { - Planning in all supply chain activities. }\end{array}$ \\
\hline Source & $\begin{array}{l}\text { - } \text { Choose green suppliers (don't damage the environment). } \\
\text { - } \text { Choose raw materials that are environmentally friendly. } \\
\text { - Environmentally friendly packaging. } \\
\text { - } \quad \text { Determine shipping requirements to minimize transportation. }\end{array}$ \\
\hline Make & $\begin{array}{l}\text { - Production scheduling to minimize energy use. } \\
\text { - Management of waste generated from the production process. } \\
\text { - Management of emissions resulting from the production } \\
\text { process. }\end{array}$ \\
\hline Deliver & $\begin{array}{l}\text { - Minimize the use of packaging in shipping. } \\
\text { - Schedule deliveries to minimize the fuel use. }\end{array}$ \\
\hline Return & $\begin{array}{l}\text { Schedule deliveries and transportation to minimize the fuel } \\
\text { use. }\end{array}$ \\
\hline
\end{tabular}

In addition to having 5 core processes (Level 1), the greenSCOR model also has performance attributes related to the company's strategy. The performance attribute (Level 2) refers to the performance attribute of the SCOR model. Each performance attribute will have different benchmarks in the greenSCOR matrix. These performance attributes will be explained in Table 4. below [10][11]:

Table 4. GreenSCOR performance attributes

\begin{tabular}{|c|l|l|}
\hline Attributes & \multicolumn{1}{|c|}{ SCOR Model } & \multicolumn{1}{c|}{ GreenSCOR Model } \\
\hline \multirow{5}{*}{ Realibility } & $\begin{array}{l}\text { Supply chain performance in } \\
\text { delivering the right product, to } \\
\text { the right place, at the right } \\
\text { time, in good condition and } \\
\text { packaging with the right } \\
\text { amount and the right } \\
\text { documents, and to the right } \\
\text { customer. }\end{array}$ & $\begin{array}{l}\text { The ability to deliver products } \\
\text { properly, reduce waste from } \\
\text { products, reduce air and fuel } \\
\text { emissions, use additional } \\
\text { transportation for product returns. }\end{array}$ \\
$\begin{array}{l}\text { Proper documentation allows all } \\
\text { parties in the supply chain to track } \\
\text { dangerous material or poisons in } \\
\text { the product, proper storage, } \\
\text { handling and disposal } \\
\text { arrangements. }\end{array}$ \\
\hline Responsiveness & $\begin{array}{l}\text { The speed of a supply chain in } \\
\text { providing products for } \\
\text { consumers. }\end{array}$ & $\begin{array}{l}\text { Environmental impacts that affect } \\
\text { the speed of movement of } \\
\text { material, including regulatory or } \\
\text { pollution control measures. }\end{array}$ \\
\hline Flexibility & $\begin{array}{l}\begin{array}{l}\text { The ability of the supply chain } \\
\text { in responding to changes in } \\
\text { market demand to obtain and } \\
\text { maintain }\end{array} \\
\text { competitive }\end{array}$ & $\begin{array}{l}\text { The extent to which companies } \\
\text { can meet the environmental } \\
\text { demands of consumers. This } \\
\text { relates to products, transportation }\end{array}$ \\
\hline
\end{tabular}




\begin{tabular}{|l|l|l|}
\hline & advantage. & and recycling. \\
\hline Costs & $\begin{array}{l}\text { Costs associated with } \\
\text { operating the supply chain. }\end{array}$ & $\begin{array}{l}\text { Costs related to the environment } \\
\text { and energy costs. }\end{array}$ \\
\hline \multirow{3}{*}{ Asset } & $\begin{array}{l}\text { The effectiveness of an } \\
\text { organization in managing } \\
\text { assets to satisfy consumers } \\
\text { including management of all } \\
\text { assets and working capital. }\end{array}$ & $\begin{array}{l}\text { Manage assets by reducing } \\
\text { environmental impact and } \\
\text { reducing internal costs. }\end{array}$ \\
\hline
\end{tabular}

\section{RESEARCH METHODS}

\section{Research Objects and Subjects}

The objects of this research is the production performance based on GSCM criteria starting from January 2017 to July 2019. While the subject of this study amounted to 7 people consisting of 3 managers, 3 supervisors and 1 officer who better know the company's business processes, especially the production process and its impact on environment.

\section{Data Collection}

In this study, PT. XYZ has not been implemented GSCM performance measurement, so the first step is to identify activities carried out in the production process by direct observation, interviews and discussions. Then proceed with the preparation of performance indicators on the Make process in the GreenSCOR process category because research focuses only on the production process. While the performance attributes used are reliability, responsiveness, flexibility, cost and assets. Furthermore, the measured performance indicators consist of 17 production performance indicators based on GreenSCOR criteria as follows:

\section{- Reliability}

1. Electricicy consumption

2. Coal usage

3. Fuel usage

4. Water usage

5. Reusable material

6. Number of engine trouble

\section{- Responsiveness}

7. The number of process reject

8. Production achievement

9. Recycleable reject

10. The number of waste

\section{- Flexibility}

11. The number of product defect

12. Accuracy of delivery quantity

13. Recycleable defect

- Cost

14. Production cost

15. Waste Management cost

- Asset

16. Production process efficiency

17. Material usage efficiency

\section{Data Processing} namely:

Data processing is done after data collection. Data processing steps in the study,

1. Calculation of the actual value of performance indicators,

2. Normalization of snorm de bour, carried out to uniform different size scales on each performance indicator so that the final value of the performance indicator is obtained, using equation (3.1) [12]:

$$
\text { Snorm }=\frac{(S I-S \text { min })}{(S \text { max }-S \text { min })} \times 100
$$

Where : 
$\mathrm{SI}=$ The actual indicator value that was achieved

$\mathrm{S} \min =$ The worst performance value of a performance indicator

$\mathrm{S} \max =$ The best performance value of the performance indicator

Determination of the worst performance value ( $\mathrm{S} \min$ ) and the best performance value ( $\mathrm{S}$ max) based on three categories, namely large is better, lower is better and nominal is better [13].

3. Weighting with AHP, carried out to determine the level of importance of each performance indicator so that it can know which performance indicators have priority, data are collected from respondents 3 level managers, 3 level supervisors and 1 level officer. The scale used for weighting in the AHP method consists of 1 to 9 with an explanation of the intensity of importance described in Table 4. [14] :

Table 4. Scale of Importance Measurement

\begin{tabular}{|c|c|l|}
\hline $\begin{array}{c}\text { Intensity of } \\
\text { Importance }\end{array}$ & Definition & \multicolumn{1}{|c|}{ Explanation } \\
\hline $\mathbf{1}$ & $\begin{array}{c}\text { Equal } \\
\text { importance }\end{array}$ & $\begin{array}{l}\text { Two elements contribute equally to the } \\
\text { objective }\end{array}$ \\
\hline $\mathbf{3}$ & $\begin{array}{c}\text { Moderate } \\
\text { importance }\end{array}$ & $\begin{array}{l}\text { Experience and judgment slightly favor } \\
\text { one element over another }\end{array}$ \\
\hline $\mathbf{5}$ & $\begin{array}{c}\text { Strong } \\
\text { importaance }\end{array}$ & $\begin{array}{l}\text { Experience and judgment strongly } \\
\text { favor one element over another }\end{array}$ \\
\hline $\mathbf{9}$ & $\begin{array}{c}\text { Very strong } \\
\text { importance }\end{array}$ & $\begin{array}{l}\text { One element is favored very strongly } \\
\text { over another, its dominance is } \\
\text { demonstrative in practice }\end{array}$ \\
\hline $\mathbf{2 , 4 , 6 , 8}$ & $\begin{array}{c}\text { Extreme } \\
\text { importance }\end{array}$ & $\begin{array}{l}\text { The evidence favoring one element } \\
\text { over another is of the highest possible } \\
\text { order of affirmation }\end{array}$ \\
\hline
\end{tabular}

4. Calculation of GSCM performance value is done by multiplying the final value of the Snorm de bour normalization performance indicator results with the AHP weight value for each performance indicator.

5. Recommendations for performance improvement or improvemet are performed on performance indicators that have a final value $<80$. The value limit is a value limit that has been set on the performance of the production process.

\section{RESEARCH RESULT AND DISCUSSION}

\section{Design and Formulation of Performance Indicators}

GreenSCOR design includes the design of performance indicators consisting of the Make process because it focuses on the production process, 5 performance attributes and 17 performance indicators. Then the formulation of performance indicators is made as a guideline for the company in measuring performance including the names of performance indicators, units and calculation formulas as show in Table 5. below. 
Table 5. GSCM Performance Indicators

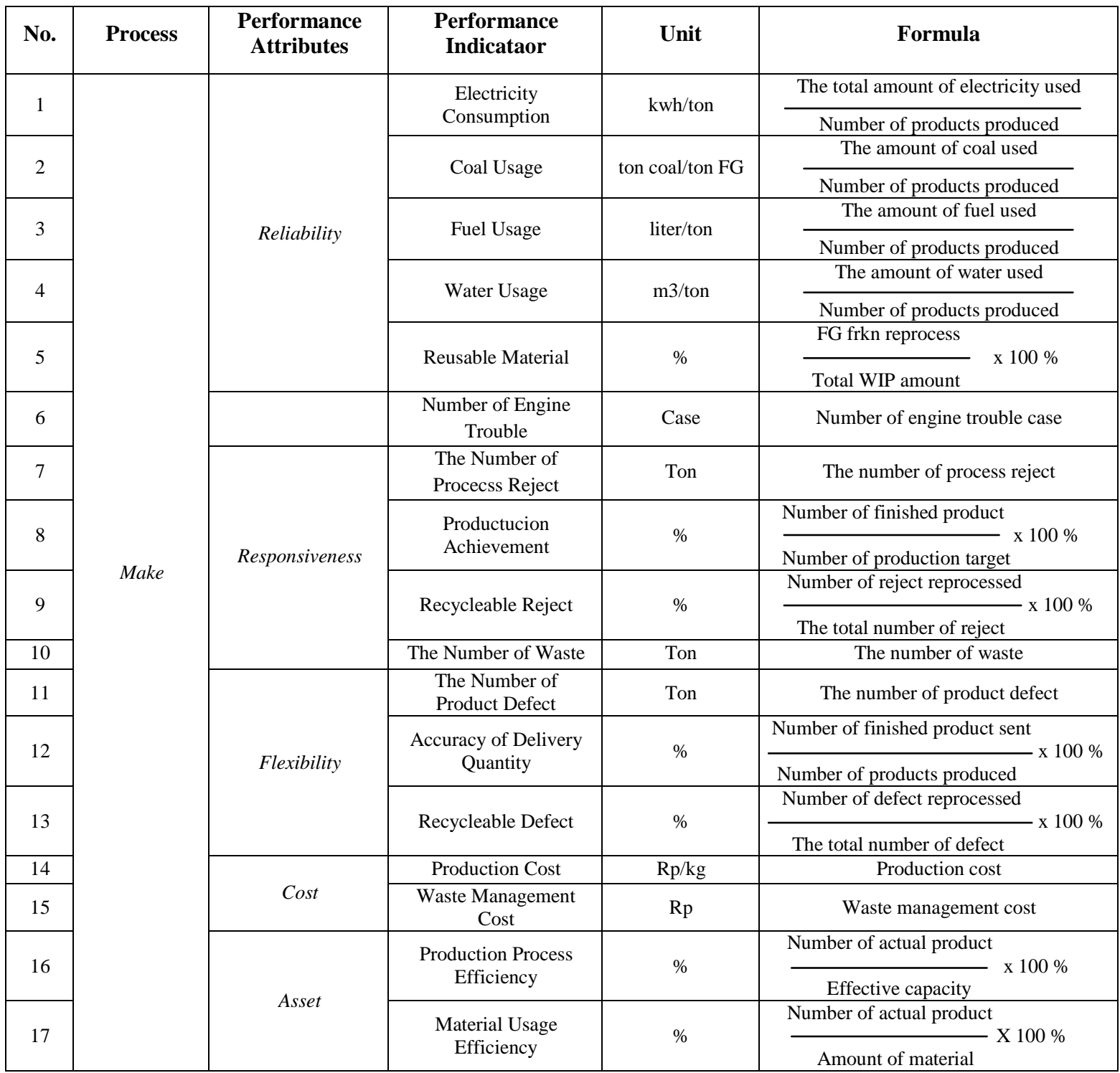

\section{Calculation of Actual Value and Final Value of Performance Indicators}

The calculation of the actual value of the performance indicator is performed using the actual data that has been collected. The calculation is done by using the formulas contained in table 5 and an example of the calculation is as follows:

- Production Achievement

Production achievement is the percentage of the number of finished products produced compared to predetermined plans. In January 2017 finished products were 5,284 tons and planned production of 6,085 tons, January 2018 finished products were 7,094 tons and planned production of 7,984 tons while in January 2019 finished products were 6,092 tons and planned production of 6,830 tons. So that the achievement of production is as follows:

$$
\begin{aligned}
\text { - January } 2017= & \frac{5.284 \text { ton }}{6.085 \text { ton }} \times 100 \%=86,8 \% \\
& 7.094 \text { ton }
\end{aligned}
$$




$$
\begin{aligned}
& \text { - January } 2018=\frac{}{7.984 \text { ton }} \times 100 \%=88,9 \% \\
& \text { - January } 2019=\frac{6.092 \text { ton }}{6.830 \text { ton }} \times 100 \%=89,2 \%
\end{aligned}
$$

- Recycleable Reject

Recycleable reject is the percentage of reject that can be recycled or reused for the production process of brine (liquid salt) compared to the total reject. This measurement aims to determine the number of rejects that can be used directly for recycling (reprocessing) in the current month into brine products that can be sold.

In July 2017 reprocess 102 tons and reject total 117 tons, July 2018278 tons and total reject 387 tons while July 2019103 tons and total reject 704 tons. So the recycleable reject is as follows:

$$
\begin{aligned}
\text { - July } 2017= & \frac{102 \text { ton }}{117 \text { ton }} \times 100 \%=88 \% \\
\text { - July } 2018= & \frac{278 \text { ton }}{387 \text { ton }} \times 100 \%=72 \% \\
\text { - July } 2019= & \frac{103 \text { ton }}{704 \text { ton }} \times 100 \%=15 \%
\end{aligned}
$$

\section{- Recycleable Defect}

Recycleable Defect is the percentage of finished products from the recycling process (reprocessing) compared to the total defect. This measurement aims to determine the number of defects that can be used directly or recycled (reprocessing) in the current month into products that can be directly sold.

In January 2017, the finished product was 11 tons and the total defect was 11 tons, January 2018 was 25 tons and the total defect was 208 tons, while in January 2019 it was 57 tons and the total reject was 130 tons. So the recycleable defect is as follows:

$$
\begin{aligned}
\text { - January } 2017= & \frac{11 \text { ton }}{11 \text { ton }} \times 100 \%=100 \% \\
\text { - January } 2018= & \frac{25 \text { ton }}{208 \text { ton }} \times 100 \%=12 \% \\
\text { - January } 2019= & \frac{57 \text { ton }}{130 \text { ton }} \times 100 \%=44 \%
\end{aligned}
$$

For other performance indicators, the calculation is almost the same as following the formula in Table 5. After obtaining the actual value of the performance indicator, then normalized using the snorm de boer according to equation (3.1), so as to produce the final value of the performance indicators in Table 6. as follows: 
Table 6. Results of Calculation of Actual and Final Value of Performance Indicators

\begin{tabular}{|c|l|c|c|c|c|c|c|c|c|}
\hline \multirow{2}{*}{ No. } & \multirow{2}{*}{ Performance Indicator } & \multicolumn{2}{|c|}{ Actual Value $($ SI } & \multirow{2}{*}{ S Min } & \multirow{2}{*}{ S Max } & \multicolumn{3}{|c|}{ Final Value } \\
\cline { 3 - 7 } & & 2017 & 2018 & 2019 & & & 2017 & 2018 & 2019 \\
\hline 1 & Electricity Consumption & 17.2 & 16.9 & 18.4 & 21 & 17 & 95 & 100 & 65 \\
\hline 2 & Coal Usage & 0.024 & 0.022 & 0.021 & 0.04 & 0.03 & 100 & 100 & 100 \\
\hline 3 & Fuel Usage & 0.52 & 0.48 & 0.45 & 0.6 & 0.4 & 40 & 60 & 75 \\
\hline 4 & Water Usage & 0.77 & 0.5 & 0.52 & 0.95 & 0.4 & 33 & 82 & 78 \\
\hline 5 & Reusable Material & $75 \%$ & $28 \%$ & $12 \%$ & $0 \%$ & $100 \%$ & 75 & 28 & 12 \\
\hline 6 & Number of Engine Trouble & 23 & 32 & 35 & 65 & 0 & 65 & 51 & 46 \\
\hline 7 & The Number of Process Reject & 105 & 96 & 84 & 125 & 15 & 18 & 26 & 37 \\
\hline 8 & Production Achievement & $89 \%$ & $90 \%$ & $87 \%$ & $50 \%$ & $100 \%$ & 78 & 80 & 75 \\
\hline 9 & Recycleable Reject & $86 \%$ & $79 \%$ & $66 \%$ & $50 \%$ & $100 \%$ & 72 & 58 & 32 \\
\hline 10 & The Number of Waste & 11.9 & 13.7 & 20.3 & 25 & 10 & 87 & 75 & 31 \\
\hline 11 & The Number of Product Defect & 44 & 63 & 52 & 80 & 10 & 51 & 24 & 40 \\
\hline 12 & Accuracy of Delivery Quantity & $98 \%$ & $98 \%$ & $98 \%$ & $85 \%$ & $100 \%$ & 87 & 87 & 87 \\
\hline 13 & Recycleable Defect & $50 \%$ & $70 \%$ & $37 \%$ & $0 \%$ & $100 \%$ & 50 & 70 & 37 \\
\hline 14 & Production Cost & 433 & 421 & 487 & 500 & 420 & 84 & 99 & 16 \\
\hline 15 & Waste Management Cost & 9.1 & 13.5 & 29.4 & 30 & 8 & 95 & 75 & 3 \\
\hline 16 & Production Process Efficiency & $67 \%$ & $74 \%$ & $65 \%$ & $0 \%$ & $100 \%$ & 67 & 74 & 65 \\
\hline 17 & Material Usage Efficiency & $95 \%$ & $96 \%$ & $96 \%$ & $0 \%$ & $100 \%$ & 95 & 96 & 96 \\
\hline
\end{tabular}

\section{Weighting of Performance Indicator}

The weighting of performance indicators is carried out to determine the level of importance of each performance indicator, because each performance indicator has different priorities. Weighting is done using the AHP method and processed using Microsoft Excel software. The results of weighting the performance indicators can be seen in Table 7 as follows:

Table 7. Results of Weighting of Performance Indicator

\begin{tabular}{|c|c|c|c|c|c|c|}
\hline $\begin{array}{l}\text { Process } \\
\text { (Level 1) }\end{array}$ & Bobot & $\begin{array}{c}\text { Performance Attributes } \\
\text { (Level 2) }\end{array}$ & Weight & $\begin{array}{c}\text { Performance Indicator } \\
\text { (Level 3) }\end{array}$ & Weight & $\begin{array}{l}\text { Final } \\
\text { Weigh }\end{array}$ \\
\hline \multirow{17}{*}{ Make } & \multirow{17}{*}{1} & \multirow{6}{*}{ Reliability } & \multirow{6}{*}{0.429} & Electricity Consumption & 0.054 & 0.023 \\
\hline & & & & Coal Usage & 0.148 & 0.063 \\
\hline & & & & Fuel Usage & 0.078 & 0.034 \\
\hline & & & & Water Usage & 0.073 & 0.032 \\
\hline & & & & Reusable Material & 0.281 & 0.121 \\
\hline & & & & Number of Engine Trouble & 0.365 & 0.157 \\
\hline & & \multirow{4}{*}{ Responsiveness } & \multirow{4}{*}{0.086} & The Number of Process Reject & 0.193 & 0.017 \\
\hline & & & & Production Achievement & 0.622 & 0.054 \\
\hline & & & & Recycleable Reject & 0.083 & 0.007 \\
\hline & & & & The Number of Waste & 0.102 & 0.009 \\
\hline & & \multirow{3}{*}{ Flexibility } & \multirow{3}{*}{0.073} & The Number of Product Defect & 0.195 & 0.014 \\
\hline & & & & Accuracy of Delivery Quantity & 0.643 & 0.047 \\
\hline & & & & Recycleable Defect & 0.161 & 0.012 \\
\hline & & \multirow{2}{*}{ Cost } & \multirow{2}{*}{0.262} & Production Cost & 0.770 & 0.202 \\
\hline & & & & Waste Management Cost & 0.230 & 0.060 \\
\hline & & \multirow{2}{*}{ Asset } & \multirow{2}{*}{0.150} & Production Process Efficiency & 0.641 & 0.096 \\
\hline & & & & Material Usage Efficiency & 0.359 & 0.054 \\
\hline
\end{tabular}

\section{Value of GSCM Performance}

Green supply chain management performance value of PT. XYZ can be known by multiplying the final value of the performance indicator with the AHP weight of each performance indicator. Then the multiplication results are all added up to find out the total GSCM performance value. The total results of GSCM performance values can be seen in Table 8 below: 
Table 8. Performance Value of Green Supply Chain Management

\begin{tabular}{|c|c|c|c|c|c|c|c|c|}
\hline \multirow{2}{*}{ No. } & \multirow{2}{*}{ Performance Indicator } & \multicolumn{3}{|c|}{ Final Value } & \multirow{2}{*}{$\begin{array}{c}\text { AHP } \\
\text { Weight }\end{array}$} & \multicolumn{3}{|c|}{ GSCM Performance Value } \\
\hline & & 2017 & 2018 & 2019 & & 2017 & 2018 & 2019 \\
\hline 1 & Electricity Consumption & 95 & 100 & 65 & 0.023 & 2.2 & 2.3 & 1.5 \\
\hline 2 & Coal Usage & 100 & 100 & 100 & 0.063 & 6.3 & 6.3 & 6.3 \\
\hline 3 & Fuel Usage & 40 & 60 & 75 & 0.034 & 1.3 & 2.0 & 2.5 \\
\hline 4 & Water Usage & 33 & 82 & 78 & 0.032 & 1.0 & 2.6 & 2.5 \\
\hline 5 & Reusable Material & 75 & 28 & 12 & 0.121 & 9.0 & 3.4 & 1.4 \\
\hline 6 & Number of Engine Trouble & 65 & 51 & 46 & 0.157 & 10.1 & 7.9 & 7.2 \\
\hline 7 & The Number of Process Reject & 18 & 26 & 37 & 0.017 & 0.3 & 0.4 & 0.6 \\
\hline 8 & Production Achievement & 78 & 80 & 75 & 0.054 & 4.2 & 4.3 & 4.0 \\
\hline 9 & Recycleable Reject & 72 & 58 & 32 & 0.007 & 0.5 & 0.4 & 0.2 \\
\hline 10 & The Number of Waste & 87 & 75 & 31 & 0.009 & 0.8 & 0.7 & 0.3 \\
\hline 11 & The Number of Product Defect & 51 & 24 & 40 & 0.014 & 0.7 & 0.3 & 0.6 \\
\hline 12 & Accuracy of Delivery Quantity & 87 & 87 & 87 & 0.047 & 4.1 & 4.1 & 4.1 \\
\hline 13 & Recycleable Defect & 50 & 70 & 37 & 0.012 & 0.6 & 0.8 & 0.4 \\
\hline 14 & Production Cost & 84 & 99 & 16 & 0.202 & 16.9 & 19.9 & 3.3 \\
\hline 15 & Waste Management Cost & 95 & 75 & 3 & 0.060 & 5.7 & 4.5 & 0.2 \\
\hline 16 & Production Process Efficiency & 67 & 74 & 65 & 0.096 & 6.4 & 7.1 & 6.3 \\
\hline 17 & Material Usage Efficiency & 95 & 96 & 96 & 0.054 & 5.1 & 5.2 & 5.2 \\
\hline \multicolumn{6}{|c|}{ The Total GSCM Performance Value } & 75.4 & 72.3 & 46.6 \\
\hline
\end{tabular}

\section{Improvements to Performance Indicators}

The first step in improving indicators is to determine performance indicators that needed to be improved. The second step is to find the root cause of the problems faced by using cause and effect diagrams. Then the third step is to propose improvements based on the root of the problem that has been obtained.

Improvements were made to the performance indicators included in the red and yellow groups in Table 4.2. This indicator has the final value of the performance indicator below the target set by the company which is more than 80 (> 80). Performance indicators with the yellow group (60-80) are electricity consumption, solar usage, water usage, production achievement and production process efficiency. While the performance indicators with the red group $(<60)$ are reusable material, the amount of machine trouble, the number of process rejects, recycleable rejects, the amount of waste, the amount of product defects, recycleable defects, production costs and waste handling costs. After knowing which performance indicators that need to be improved, then the root of the problem is searched by using cause and effect diagrams.

\section{Discussion}

\section{- Designing and Weighting Performance Indicators}

The design of green supply chain management performance indicators begins with identifying existing business processes in the company, in this case PT. XYZ There are 6 business processes in PT. XYZ namely planning, procurement of raw materials, production 
processes, product distribution, product returns from consumers, and waste management. Because the focus of research on the production process, the next step is to divide the make process categories into 5 performance attributes, namely reliability, responsiveness, flexibility, cost and assets. After that each performance attribute is broken down into performance indicators totaling 17 performance indicators as shown in Figure 2 below:

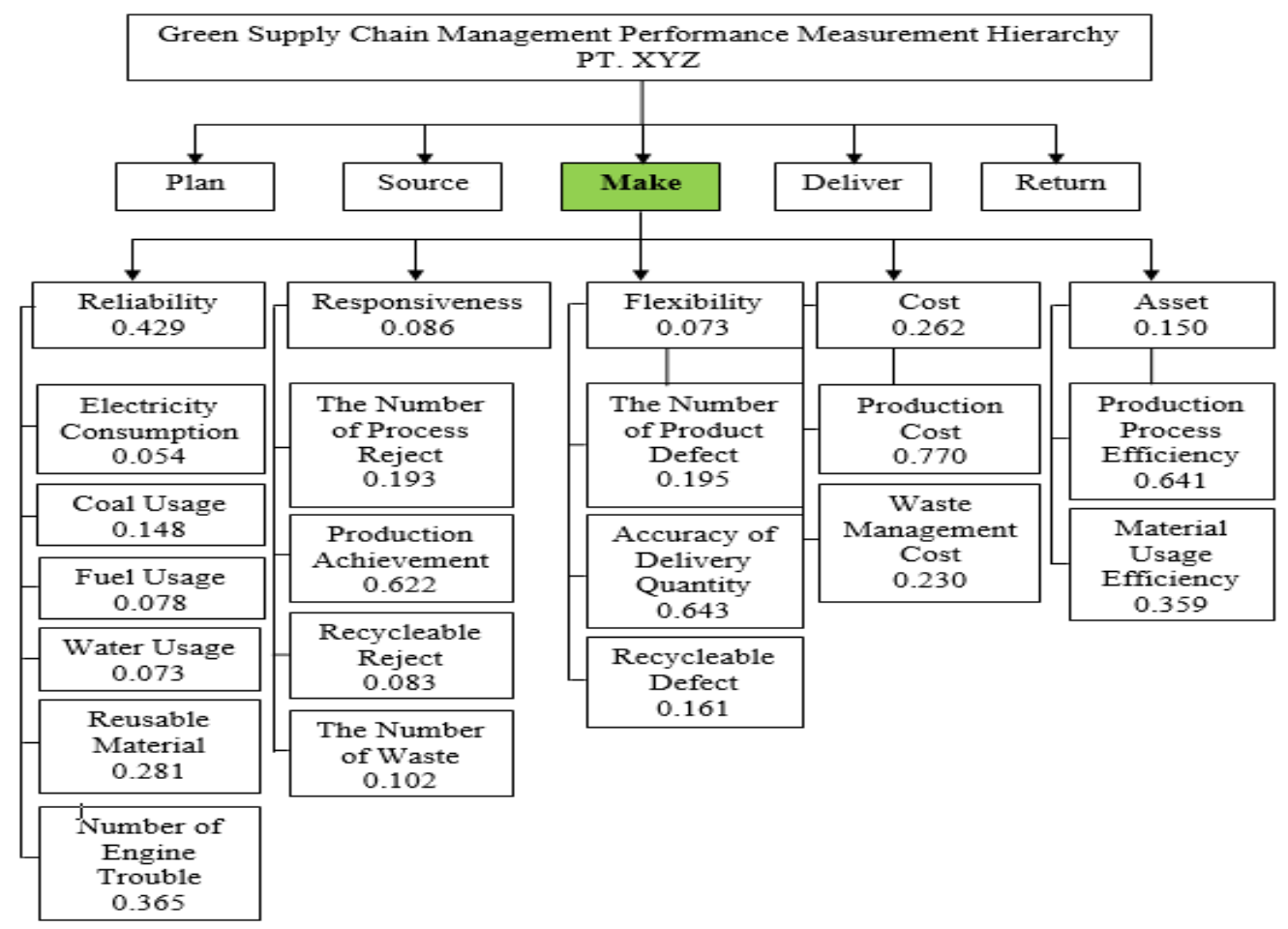

Figure 2. Hierarchy and Weight of Performance Indicators (Source: Excell software data processing results)

\section{- Analysis and Improvement of Performance Indicators}

Based on the calculations done in Table 8 , it can be seen that the value of the performance of the green supply chain management as a whole in the production process of PT. XYZ measured from 2017 to July 2019 declined and is far below the target, so immediate improvement needs to be done. This is indicated by the total value of the performance of the green supply chain management obtained in 2017 amounted to 75.4, December 2018 amounted to 72.3 while January - July 2019 amounted to 46.6.

The low value above is caused by 9 performance indicators that fall into the red group $(<60)$ and need to be corrected immediately. The nine performance indicators are reusable material, the amount of machine trouble, the number of process rejects, recycleable rejects, the amount of waste, the amount of product defects, recycleable defects, production costs and waste handling costs.

The results of the identification of problems using cause and effect diagrams and recommendations for improvement for each performance indicator are as follows:

\section{Reusable Material}

Improvement recommendations for reusable material performance indicators are:

- Coordination between PPIC, sales and related teams focus on WIP and reprocessing to FG.

- Increase reprocess capacity.

- Improved WIP storage method to make it more durable and stable water content. 
- Coordination between the operation and sales team so as not to add WIP when there are changes in product specifications.

\section{Number of Engine Trouble}

Improvement recommendations for reusable material performance indicators are:

- Changes in engine design and supplier alternative spare parts.

- The maintenance plan is carried out accurately, periodically and thoroughly.

- Procurement is more active so that it is not a single supplier.

- Coordination between PPIC and the sales team so that delivery schedules are more accurate.

\section{The Number of Process Reject}

Improvement recommendations for reusable material performance indicators are:

- Improvements to the pipe connection system so that it is tightly closed.

- Repair of stockpile floors and walls.

- Improvements to the WIP storage method so it will not be rejected.

- Increased leader supervision of all process stations.

\section{Recycleable Reject}

Improvement recommendations for reusable material performance indicators are:

- Increase the number of brine customers.

- Reduction of local salt washing processes and non-washing salt processes.

- Look for alternative products other than brine from reject reprocess.

- Looking for alternative machines to reprocessing rejects products into raw materials.

5. The Number of Waste

Improvement recommendations for reusable material performance indicators are:

- Installation of circulation pumps.

- Coal incoming must be more selective and look for by alternative suppliers.

- Making SOP and socializing the grit reactor process.

- Control clock settings alternately.

\section{The Number of Product Defect}

Improvement recommendations for reusable material performance indicators are:

- Making a standard of screen mesh size combination and repair of stockpile floors and walls.

- Screen mounting method according to SOP and iodine dozing improvement.

- Procurement of anticaking gauges.

- Manpower settings for manual sorting.

\section{Recycleable Defect}

Improvement recommendations for reusable material performance indicators are:

- Coordination between PPIC, sales and related teams focus on Hold product (defect) and reprocessing to FG.

- Preventive and Plan maintenance is carried out for the mainline engine and each line.

- Improved defect storage methods to make it more durable and not be rejected.

\section{Production Cost}

Improvement recommendations for reusable material performance indicators are:

- Improve product quality checking and improve production performance.

- Maintenance plans are carried out accurately and according to priority.

- Procurement of automatic packing machines and bagging machines.

\section{Waste Management Cost}

Improvement recommendations for reusable material performance indicators are:

- Installation of circulation pumps. 
- Assessment of making a waste treatment unit.

- The focus of routine handling and evaluation of the amount of waste produced.

\section{REFERENCES}

[1] Mukharromah, I.N, Deoranto, P, Mustaniroh, S.A. dan Sita, K. (2017). Analisis Pengukuran Kinerja Perusahaan Dengan Metode Green Supply Chain Management (GSCM) di Unit Bisnis Teh Hitam. Jurnal Penelitian Teh dan Kina. Vol. 20 No. 1, hal 48-58.

[2] Camgoz, H.A. and Beldek, T. (2017). Waste Management in Green Building Operations Using GSCM. International Journal Supply of Supply Chain Mangement. Vol. 6 No. 3.

[3] Susanty, A, Santosa, H, dan Tania, F. (2017). Penilaian Implementasi Green Supply Chain Management di UKM Batik Pekalongan dengan Pendekatan GreenSCOR. Jurnal Ilmiah Teknik Industri. Vol. 16 No. 1, hal 55-63.

[4] Sutawidjaya, A. H dan Marlapa, Eri. (2016). "Supply Chain Management: Analisis dan Penerapan Menggunakan Reference (SCOR) di PT. Indoturbine”. Jurnal MIX: Jurnal Ilmiah Manajemen. Vol. VI, No. 1, Hal. 121-138. Universitas Mercu Buana.

[5] Bowersox, D.J. Closs, D. J. and Cooper, M. B. (2002). Supply Chain Logistics Management. McGrawHill. USA.

[6] Penfield, P. (2007). Sustainability can be competitive advantage. Whitman School of Management.

[7] Ninlawan, C., Seksan, P., Tossapol, K., (2010). The Implementation of Green Supply Chain Management Practices in Electronic Industry. Proceeding of The International Multiconference of Engineers and Computer Scientists.

[8] Sutawidjaya, A. H., Nawangsari L.C., dan Suharno. (2017). "A Framework Distribution Strategis on Green Supply Chain Management”. Seminar Nasional Inovasi Dan Aplikasi Teknologi di Industri 2017. ITN Malang, 4 Februari 2017.

[9] Taylor, W (2003). GreenSCOR: Developing a Green Supply Chain Analytical Tool. Washington DC.

[10] SCC (2010). Supply Chain Operations Reference Model Revision 10.0. United States of America: SCC.

[11] Cash, R. and Wilkerson, T. (2003). GreenSCOR: Developing a Green Supply Chanin Analytical Tools. Washington DC: Logistics Management Institute.

[12] Trienekens, J. H and Hvolby, H.H. (2000). Performance Measurement and Process. Pittsburgh: RWS Publications.

[13] Hernan, S. dan Suparno (2005), "Evaluasi Supplier dengan Pendekatan Vendor Performance Indikator dan Metode Analytical Hierarchy Process". Prosiding Seminar Nasional Manajemen Teknologi II. Program Studi MMT ITS, hal A8.1 - A8.11.

[14] Saaty, T. L. (1993). Pengambilan Keputuan Bagi Para Pemimpin. PT. Pustaka Binaman Pressindo. Jakarta. 